UDC [631.563:635.156]:678.048

DOI: 10.15587/2706-5448.2021.235533

Article type «Original research»

\section{Olesia Priss, \\ Valentina Zhukova, \\ Serhii Holiachuk, \\ Tetiana Karman}

\title{
EFFECT OF HEAT TREATMENT WITH BIOPREPARATION ON THE QUALITY OF TOMATO FRUIT DURING STORAGE
}

Tomato fruits are characterized by a high content of biologically active substances, which makes them an irreplaceable component of nutrition. However, tomatoes are perishable products and require additional measures to extend storage. One of the most problematic areas is the limited use of synthetic chemicals for processing fruit prior to storage. An alternative to them are natural exogenous preparations with antioxidant and disinfectant effects, which are environmentally friendly. However, the treatment of fruits with natural substances does not have sufficient efficiency in comparison with synthetic ones, which requires a combination with other post-harvest measures to increase cold stress. The object of research is the process of storing tomato fruits using heat treatment with a biological product. Numerous studies indicate the feasibility of using the processing of fruits with biological products to extend their storage duration. Standardized preparations based on bee products are of great interest. The research carried out in this work is aimed at extending the shelf life of tomato fruits while maintaining their quality by heat treatment of tomatoes with a solution of a biological product (tincture of the biomass of the larvae of the greater wax moth) before storage. In the course of the study, it was found that such treatment prolongs the shelf life of blank tomatoes up to 50 days, which is $40 \%$ longer compared to the control. It has been proven that fruits treated with a biological product demonstrate a low level of metabolic processes. This is due to the fact that the proposed treatment slows down the rate of accumulation and degradation of sugars and organic acids. In particular, in fruits treated with a biological product, the sugar content is $8.8-10.6 \%$ higher than in the control. The rate of decrease in the level of titratable acidity in the variants treated with the biological product is 15-19\% slower than in the control. The above results indicate the effectiveness of the use of a biological product for storing tomato fruits in comparison with similar measures.

Keywords: storage of tomatoes, tincture of biomass of the larvae of the greater wax moth, sugar content, titratable acidity.

Priss, O., Zhukova, V., Holiachuk, S., Karman, T. (2021). Effect of heat treatment with biopreparation on the quality of tomato fruit during storage. Technology Audit and Production Reserves, 3 (3 (59)), 40-45. doi: http://doi.org/10.15587/2706-5448.2021.235533

\section{Introduction}

The world food problem is associated mainly with the growth of the world's population, a shortage of resources, and an increase in anthropogenic impact on ecosystems. The main ways to solve it are the promotion of sustainable and healthy diets based on plant products and the reduction of food waste and food losses, including post-harvest losses [1]. According to FAO statistics [2], $44 \%$ of all losses of food resources are losses of fruits and vegetables. On average, losses for perishable crops such as fruits and vegetables are $6.4 \%$ compared to $2.7-3.8 \%$ for other crops. In addition, post-harvest losses of fruits and vegetables in low- and middle-income countries are 10-15\%, while, for example, in Europe and North America, only 4-7 \% [3].

Today, scientists have developed a number of technological aspects designed to reduce the loss of fruit and vegetable products $[4,5]$. However, the problem remains relevant for scientists around the world.
Among all groups of vegetable crops, fruit vegetables have the lowest shelf life, the most popular of which are tomatoes. It is the dominant vegetable crop in the European market [6]. Tomato fruits are characterized by high phytonutrients, which makes them an irreplaceable component of human nutrition [7,8].

\section{The object of research and its technological audit}

The object of research is the process of storing tomato fruits using heat treatment with a biological product.

One of the most problematic areas in the selection of chemicals for processing fruit prior to storage is the limited use of synthetic chemicals. Their characteristic disadvantages are potential negative effects on human health and the environment. The obvious risk factor raises concern and contributes to the search for environmentally friendly natural preparations with antioxidant and disinfecting effects, 
which are alternative to synthetic ones. However, often the treatment of fruits with natural substances does not have sufficient efficiency compared to synthetic ones, which requires a combination with other post-harvest measures to increase cold stress.

\section{The aim and objectives of research}

The aim of research was to lengthen the shelf life of tomato fruits while maintaining their quality by inactivating pathogenic and epiphytic microflora from the surface of tomatoes with a solution of a biological product before storing them.

To achieve this aim, the following objectives were set:

1. To establish the optimal concentration of the biological product to maximize the storage duration of tomato fruits while maintaining their quality.

2. To investigate the peculiarities of the influence of a biological product on the commercial quality and biochemical parameters of fruits during storage.

\section{Research of existing solutions to the problem}

Scientists pay much attention to the development and improvement of fruit storage technologies based on the use of safe, environmentally friendly methods and natural components for post-harvest processing [9, 10]. Numerous studies indicate the advisability of using treatment with exogenous biological products to increase the shelf life without losing the quality and biological value of the fruits. Scientists have developed complex compositions of antioxidant action, the treatment with which effectively increases the resistance of fruits to cold stress during storage [11, 12]. Among antioxidant substances for processing fruits, ionol, dimethyl sulfoxide, lecithin, chlorophyllipt, ascorbic acid, as well as plant extracts and biological products are most often used [13-15].

Preparations based on bee products, which are standardized in medicine and are actively used to treat a number of diseases, are of great interest. The world scientific community recommends their use due to the high biological value of such products, anti-inflammatory, bactericidal, fungicidal, antiviral, antioxidant activity [16]. In addition, biological products based on beekeeping products are used for the primary processing of fruits and for increasing the storage duration [17, 18].

The biomass of the greater wax moth has been studied in detail by scientists. Tincture of the biomass of the larvae of the greater wax moth (BLGWM) is produced by the pharmacological production of Ukraine. It has undergone preclinical pharmaco-technological, physicochemical studies, according to which it is not toxic, not pathogenic, is characterized by a therapeutic and prophylactic effect, and has no side effects $[19,20]$. This biological product is characterized by therapeutic and prophylactic, immunomodulatory properties due to its rich chemical composition: essential amino acids, unsaturated fatty acids, hormones, enzymes, sugars, vitamins, microelements. BLGWM tincture is safe, has antimicrobial and antioxidant properties. The antimicrobial effect of the drug was found against gram-positive and gram-negative bacteria, mycobacterium tuberculosis and pathogenic fungi. The antioxidant effect is due to the content of tocopherols and ascorbic acid.
Microorganisms enter the fruit at all stages of the technological production chain: during the growing season, collection, storage, packaging, sale. The use of antimicrobial drugs in the technology of pre-harvest processing or storage is highly effective [21]. Thus, the use of a biological product with a pronounced antimicrobial activity to increase the storage duration of tomato fruits can be promising and requires scientific research in this direction.

At the National Scientific Center «Institute of Beekeeping named after P. I. Prokopovich» (Kyiv, Ukraine), a technology for preparing BLGWM tincture under the Gretavisk trademark has been developed. For this, the properties of the larvae were studied depending on age, the optimal algorithm of the tincture preparation technology was presented, and the Technical Conditions of Ukraine were approved for it [22]. The normative document TU U 01.2-00729557.002-2002 contains requirements for quality indicators for the BLGWM tincture, which guarantee high quality and safety of the biological product, describing the process of its production.

\section{Methods of research}

The effectiveness of the technology of primary processing and storage of tomato fruits depends on the observance of many factors and the consistent performance of all technological operations: transportation, inspection, sorting, calibration, processing of fruits with a biological product, drying, storage and sale. Tomatoes must be healthy, clean, free of mechanical damage, signs of wilting, defects, diseases and extraneous moisture. Primary processing and storage measures aimed at adapting the processes of fruit viability, reducing the negative influence of external factors and stress factors.

Tomatoes were used for storage, a mid-season variety Katiusha F1, blanc degree of ripeness, flat-rounded, dense, characterized by high keeping quality and transportability.

The fruits were harvested by hand in the morning in dry, clear weather, typical in color and shape. Blanc fruits were immersed in a solution of BLGWM tincture at a concentration of 1,3 , and $5 \%$ at a temperature of $45{ }^{\circ} \mathrm{C}$ for $15 \mathrm{~min}$. The temperature and exposure of heat treatment were selected based on literature data and previous studies [23]. The fruits were dried, put into plastic boxes, cooled and stored at $12 \pm 1{ }^{\circ} \mathrm{C}$, relative air humidity $85-90 \%$. Untreated fruits (K1) and fruits treated with a $5 \%$ aqueous solution of alcohol (K2) were taken as control. A schematic flow diagram of the primary processing and storage of tomato fruits is shown in Fig. 1.

In the course of the research, changes in the commercial quality and some biochemical parameters of tomato fruits during storage were studied.

Experimental experiments were carried out in 2019-2020 in the laboratory of technology for primary processing and storage of crop products of the Research Institute of Agrotechnology and Ecology of the Tavrichesk State Agrotechnological University named after Dmytro Motorny.

In the course of research, in accordance with generally accepted methods, the commercial quality, total sugar content, titratable acidity were determined, and organoleptic assessment was carried out.

Sampling and preparation of samples for analyzes was carried out in accordance with DSTU ISO 874-2002. Commodity analysis - in accordance with DSTU 3246-95. 
Organoleptic evaluation - in accordance with the guidelines for storage and processing of crop products. Physiological and microbiological diseases were determined by examining the fruits and distributing them according to the type of lesion. The end of the storage time was determined by the total loss of fruits, no more than $10 \%$.

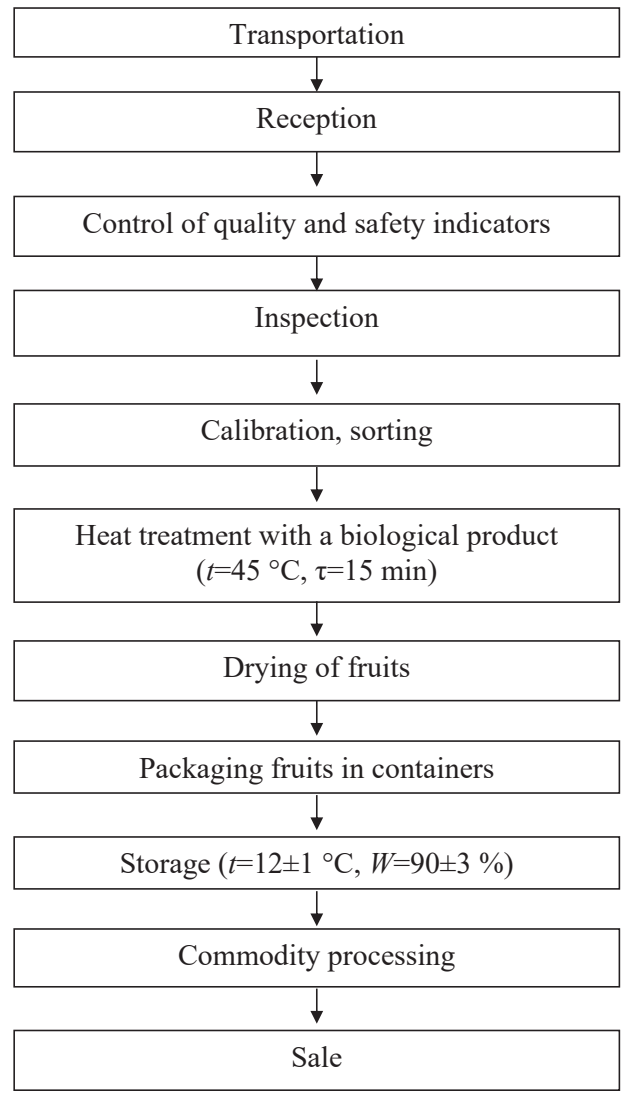

Fig. 1. Basic technological scheme of primary processing and storage of tomato fruits

The mass concentration of sugar was determined according to DSTU 4954:2008; titrated acids - according to DSTU4957:2008. Mathematical processing of the research results was carried out according to V. Moiseichenko and the computer program «Excel 2010».

\section{Research results}

The commercial quality of fruits is a complex indicator that determines their competitiveness in the market. It combines a number of tomato-specific characteristics: biochemical, physical, biological, which are determined by the genotype and the level of its implementation in the corresponding growing region.

The commercial quality of tomato fruits supplied and sold for fresh consumption, as well as for further storage, is regulated by the state standard DSTU 3246-95 «Fresh Tomatoes. Technical conditions».

Consumers give preference to beautiful, uniformly colored, dense fruits with high taste characteristics; when choosing fruits, their appearance, nutritional and technological value, shelf life, transportability, environmental friendliness and safety are assessed.

The quality of tomatoes, their commercial and consumer properties are formed during the growing season, during ripening on the mother plant [24,25]. It is influenced by a combination of many factors, among which the main ones are the biological characteristics of the variety, soilclimatic and agrotechnical conditions of cultivation [26-28].

Tomatoes of the corresponding variety under specific conditions are characterized not only by certain external indicators, ripening time, but also by a special chemical composition, which can be predicted depending on the level of abiotic factors [29].

After 30 days of storage, among the control variants, according to the commercial characteristics, the best indicators were in the fruits treated with an aqueous solution of alcohol (Table 1), which can be easily explained by a certain bacteriostatic effect of the treatment.

The maximum number of standard fruits after 50 days of storage was in the variants of the BLGWM finishing with concentrations of 3 and $5 \%$. However, the difference in the yield of standard products between the variants with the concentration of the biological product of 3 and $5 \%$ is unreliable. This testifies to the inexpediency of increasing the concentration of the BLGWM tincture.

The decrease in the yield of standard products was due to physiological disorders - the wilting of the fruits. Table 2 shows the loss of fruits from physiological disorders and microbiological diseases after storage.

After 30 days of storage of the control groups, a higher level of microbiological damage was in the K1 option $8.0 \%$. On the contrary, in option K2, only $2.4 \%$ of the fetuses have signs of microbiological diseases. Losses from physiological fetal disorders in options $\mathrm{K} 1$ and $\mathrm{K} 2$ were at the level of 5.45 and $6.01 \%$, respectively.

The level of fruits affected by microorganisms after 50 days of storage was significantly lower in the finishing options for BLGWM with concentrations of 3 and $5 \%$ and amounted to 0.7 and $0.5 \%$, respectively. During storage of research groups of fruits, losses from functional disorders were significantly lower in treatments with concentrations of 3 and $5 \%$ and averaged $4.5 \%$.

Commercial quality of tomatoes after storage, $\%, M \pm m, n=3$

Tahle 1

\begin{tabular}{|c|c|c|c|c|c|c|}
\hline \multirow{2}{*}{ Option } & \multirow{2}{*}{$\begin{array}{c}\text { Storage duration. } \\
\text { days }\end{array}$} & \multicolumn{4}{|c|}{ Products. \% } & Tasting scare. \\
paint
\end{tabular}




\begin{tabular}{|c|c|c|c|}
\hline Option & $\begin{array}{l}\text { Storage dura- } \\
\text { tion, days }\end{array}$ & $\begin{array}{c}\text { Physiological } \\
\text { diseases, \% }\end{array}$ & $\begin{array}{l}\text { Microbiological } \\
\text { diseases, \% }\end{array}$ \\
\hline K1 & \multirow{2}{*}{30} & $6.01 \pm 0.45$ & $8.03 \pm 0.25$ \\
\hline К2 & & $5.45 \pm 0.19$ & $2.39 \pm 0.17$ \\
\hline BLGWM 1 \% & 40 & $8.89 \pm 0.05$ & $2.17 \pm 0.22$ \\
\hline BLGWM 3 \% & \multirow{2}{*}{50} & $4.59 \pm 0.12$ & $0.70 \pm 0.08$ \\
\hline BLGWM 5 \% & & $4.39 \pm 0.10$ & $0.52 \pm 0.07$ \\
\hline $\mathrm{HIP}_{05}$ & - & 0.51 & 0.09 \\
\hline
\end{tabular}

According to the results obtained, the treatment of fruits with a biological product based on a tincture of BLGWM lengthens the shelf life of tomato fruits and increases the yield of standard fruits in comparison with control samples.

The taste indicators of tomato fruits are determined by the level of sugars, organic acids and their ratio. The composition of dry matter of tomatoes is dominated by carbohydrates, mainly simple saccharides [7, 30].

The dynamics of the total content of saccharides in fruits during storage is shown in Fig. 2. The dashed curves shown in the graph characterize the probable form of dependences.

During storage, the blank fruits of the tomato ripen, therefore the sugar content increases. In the control group of fruits, the maximum level of simple carbohydrates is observed on the 20th day, then the biosynthesis process stops and the aging process begins. Fruits treated with BLGWM ripen more slowly, the process lasts up to 40 days. And, accordingly, the processes of overripening of the research group of fruits occur later. And this leads to a 8.8-10.6\% high saccharide content in comparison with the control options.

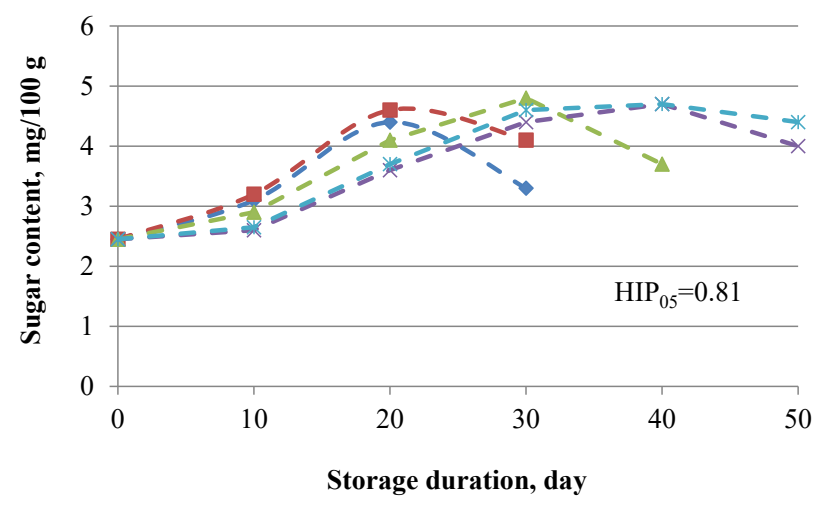

$-\leftarrow$ K1 - K2 - BLGWM $1-x-$ BLGWM $3-*-$ BLGWM 5

Fig. 2. Dynamics of the sugar content in tomatoes during storage

Tomatoes contain citric, malic, oxalic and fumaric acids [31]. Lemon is predominant. During storage, acids act as a substrate for respiration, which leads to a gradual decrease in their content (Fig. 3). The dashed curves shown in the figure characterize the probable form of dependences.

The rate of consumption of acids in the variants treated with the biological product is $15-19 \%$ slower, which indicates a lower level of metabolic processes in the tomatoes of the experimental samples.

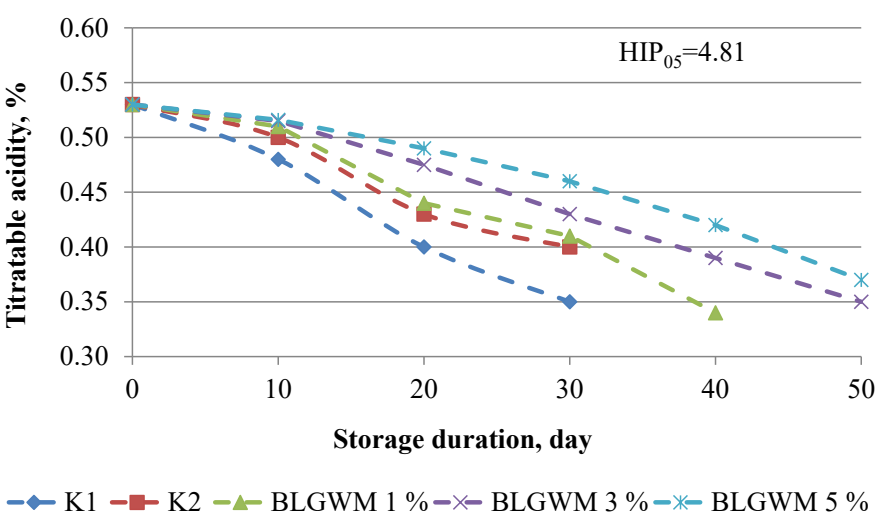

Fig. 3. Dynamics of titratable acidity in tomatoes during storage

\section{SWOT analysis of research results}

Strengths. The positive effect of the research is the choice of an effective natural biological product for heat treatment of tomato fruits before storage. In the course of the research, it was possible to establish the optimal concentration of the biological product to maximize the storage time of tomatoes while maintaining their quality. This was facilitated by the study of the peculiarities of the effect of heat treatment with a biological product on the commercial quality and biochemical parameters of fruits during storage.

Weaknesses. The weak side of the research is the analysis of the effect of this treatment exclusively on the commercial quality and biochemical parameters of tomatoes, and not covering the complex of endogenous antioxidants. However, the study of the dynamics of all antioxidants in tomato fruits will lead to overload and difficult perception of this work.

Opportunities. The prospect of further research is the analysis of the effect of heat treatment with a biological product on endogenous antioxidants of tomatoes. The results of the work will be reflected in a separate work, which will allow to understand the complex mechanism of the influence of this processing. The implementation of the results obtained will allow to extend the period of tomato supply to consumers both in Ukraine and around the world.

Threats. For the effective use of this technology, it is necessary to additionally take into account the annual fluctuations in the biochemical parameters of tomatoes, depending on the weather and climatic conditions of growing. When implementing the research results, additional costs are required. In particular, when processing tomato fruits with a biological product, the storage cost increased to $170 \mathrm{USD} / \mathrm{t}$, and the net profit amounted to $52 \mathrm{USD} / \mathrm{t}$, while the profitability of fruit storage was $16.03 \%$ higher compared to the control.

\section{Conclusions}

1. It has been established that heat treatment of tomato fruits with a tincture of BLGWM at a concentration of $3 \%$ allows to increase the storage time of blanche fruits up to 50 days, which is $40 \%$ longer than in the control. An increase in the concentration of a biological product does not lead to an increase in the shelf life. The maximum number of standard fruits after 50 days of storage was 
in variants 3 and $5 \%$ BLGWM - 88.71 and $89.79 \%$, respectively. Since a high BLGWM concentration does not significantly increase the yield of standard products or extend shelf life, a concentration of $3 \%$ is preferred.

2. It has been proven that fruits treated with a biological product demonstrate a low level of metabolic processes. This is confirmed by the slower rates of accumulation and degradation of sugars and organic acids. In fruits treated with a biological product, sugars are 8.8-10.6 \% higher than in the control. The rate of decrease in the level of titratable acidity in the variants treated with the biological product is slower - by 15-19\% compared to the control. The above results indicate the effectiveness of the use of the preparation from the biomass of the larvae of the greater wax moth for storing tomato fruits.

\section{References}

1. El Bilali, H., Callenius, C., Strassner, C., Probst, L. (2018). Food and nutrition security and sustainability transitions in food systems. Food and Energy Security, 8 (2), e00154. doi: http://doi.org/10.1002/fes3.154

2. Lipinski, B., Hanson, C., Lomax, J., Kitinoja, L., Waite, R., and Searchinger, T. (2013). Reducing Food Loss and Waste. Working Paper, Installment 2 of Creating a Sustainable Food Future. Washington. Available at: https://pdf.wri.org/reducing_food_loss_and_waste.pdf

3. Fabi, C., Cachia, F., Conforti, P., English, A., Rosero Moncayo, J. (2021). Improving data on food losses and waste: From theory to practice. Food Policy, 98, 101934. doi: http://doi.org/10.1016/ j.foodpol.2020.101934

4. Serdyuk, M., Baiberova, S., Gaprindashvili, N., Sukharenko, E. (2017). The effect of treatment wiih antioxidant compositionon on the number of standard fruits after the coid storage. Bulletin of the National Technical University «KhPI» Series: New Solutions in Modern Technologies, 23 (1245), 176-181. doi: http:// doi.org/10.20998/2413-4295.2017.23.28

5. Zahorko, N. P., Struchaiev, M. I., Tarasenko, V. H. (2018). Vyrobnytstvo aerovanykh zamorozhenykh produktiv. Visnyk Ukrainskoho viddilennia Mizhnarodnoi akademii ahrarnoi osvity, 6, 124-133.

6. Capobianco-Uriarte, M. de las M., Aparicio, J., De Pablo-Valenciano, J., Casado-Belmonte, M. del P. (2021). The European tomato market. An approach by export competitiveness maps. PLOS ONE, 16 (5), e0250867. doi: http://doi.org/10.1371/ journal.pone.0250867

7. Priss, O., Kalytka, V. (2014). Enzymatic antioxidants in tomatoes and sweet bell pepper fruits under abiotic factors. Ukrainian Food Journal, 3 (4), 505-663.

8. Erika, C., Griebel, S., Naumann, M., Pawelzik, E. (2020). Biodiversity in Tomatoes: Is It Reflected in Nutrient Density and Nutritional Yields Under Organic Outdoor Production? Frontiers in Plant Science, 11. doi: http://doi.org/10.3389/ fpls.2020.589692

9. Hasan, M. U., Riaz, R., Malik, A. U., Khan, A. S., Anwar, R., Rehman, R. N. U., Ali, S. (2021). Potential of Aloe vera gel coating for storage life extension and quality conservation of fruits and vegetables: An overview. Journal of Food Biochemistry, 45 (4). doi: http://doi.org/10.1111/jfbc. 13640

10. Romanazzi, G., Feliziani, E., Baños, S. B., Sivakumar, D. (2016). Shelf life extension of fresh fruit and vegetables by chitosan treatment. Critical Reviewes in Food Science and Nutrition, 57 (3), 579-601. doi: http://doi.org/10.1080/10408398.2014.900474

11. Priss, O. P. (2017). Naukovi osnovy zberihannia plodovykh ovochiv z vykorystanniam obrobky biolohichno aktyvnymy rechovynamy. Kyiv, 45.

12. Zhukova, V. F., Haprindashvili, N. A., Sukharenko, O. I., Koliadenko, V. V. (2019). Effect of antioxidant treatment of fruits on the quality preservation of tomato heterorosis sort with genes of lower reduction. Proceedings of the Tavria State agrotechnological university, 3 (19), 268-275.
13. Ali, S., Anjum, M. A., Nawaz, A., Naz, S., Hussain, S., Ejaz, S. Sardar, H. (2020). Effect of pre-storage ascorbic acid and Aloe veragel coating application on enzymatic browning and quality of lotus root slices. Journal of Food Biochemistry, 44 (3). doi: http://doi.org/10.1111/jfbc.13136

14. Anjum, M. A., Akram, H., Zaidi, M., Ali, S. (2020). Effect of gum arabic and Aloe vera gel based edible coatings in combination with plant extracts on postharvest quality and storability of «Gola» guava fruits. Scientia Horticulturae, 271 , 109506. doi: http://doi.org/10.1016/j.scienta.2020.109506

15. Sanches, A. G., Costa, J. M., Silva, M. B., Moreira, E. G. S. Cosme, S. S. (2017). Tratamentos Químicos na Manutenção da Qualidade Pós-Colheita em Frutos de Pitanga (Eugenia uniflora L.) Nativa, 5 (4), 257-262. doi: http://doi.org/10.5935/2318-7670. $\mathrm{v} 05 \mathrm{n} 04 \mathrm{a} 05$

16. Tykhonov, O. I., Konoshevych, L. V., Kudryk, B. T., Bobro, S. H. (2014). Relevance the creation in Ukraine drugs preparations of bee products (Apitherapy). Zbirnyk naukovykh prats spivrobitnykiv NMAPO im. P. L. Shupyka, 23 (3), 434-439. Available at: http://nbuv.gov.ua/UJRN/Znpsnmapo_2014_23\%283\%29_66

17. Santos, E. X. D., Repolho, R. P. J., Sanches, A. G., Lima, K. S. (2020). The preservative effect of bee wax and calcium chloride coating on the quality and firmness of graviolas (Annonamuricata L.). MOJ Food Process Technol, 8 (2), 32-38.

18. El-Moneim, E. A. A. Abd., Hany, M., Zeinab, A. Z., Abo, M. E. A. (2015). Effect of Honey and Citric Acid Treatments on Postharvest Quality of Fruits and Fresh-Cut of Guava. World Journal of Agricultural Sciences, 11, 255-267.

19. Bohutska, O. Ye. (2020). Dosvid zastosuvannia lychynok vohnivky bdzholynoi ta trutnevoho rozplodu dlia stvorennia likarskykh zasobiv shyroko spektru farmakolohichnoi dii. Zastosuvannia metodiv likuvannia i apipreparativ u medychnii, farmatsevtychnii ta kosmetychnii praktytsi. Kharkiv: Vyd-vo NFaU, 64-65.

20. Bohutska, O. Ye., Tykhonov, O. I. (2018). Lychynky vohnivky bdzholynoi - syrovyna dlia stvorennia preparativ dlia korektsii vikovykh zmin u orhanizmi. Kosmetolohiia ta aromolohiia: etapy stanovlennia i maibutnie. Kharkiv, 35.

21. Chen, J., Shen, Y., Chen, C., Wan, C. (2019). Inhibition of Key Citrus Postharvest Fungal Strains by Plant Extracts In Vitro and In Vivo: A Review. Plants, 8 (2), 26. doi: http://doi.org/ 10.3390 plants 8020026

22. Shpychak, O. S. (2005). Rozrobka skladu ta tekhnolohii novoho kompleksnoho pryrodnoho preparatu z antymikrobnymy ta imunomoduliuiuchymy vlastyvostiamy. Kharkiv, 28.

23. Priss, O. P. (2015). Chilling-injury reduction during the storage of tomato fruits by heat treatment with antioxidants. EasternEuropean Journal of Enterprise Technologies, 1 (6 (73)), 38-43. doi: http://doi.org/10.15587/1729-4061.2015.37171

24. Priss, O. P., Zhukova, V. F. (2013). Zalezhnist urozhainosti ta pokaznykiv yakosti plodiv tomata vid pohodnykh umov. Visnyk Poltavskoi derzhavnoi ahrarnoi akademii, 1, 49-51.

25. Gautier, H., Diakou-Verdin, V., Bénard, C., Reich, M., Buret, M. Bourgaud, F. et. al. (2008). How Does Tomato Quality (Sugar, Acid, and Nutritional Quality) Vary with Ripening Stage, Temperature, and Irradiance? Journal of Agricultural and Food Chemistry, 56 (4), 1241-1250. doi: http://doi.org/10.1021/jf072196t

26. Gruda, N. (2005). Impact of Environmental Factors on Product Quality of Greenhouse Vegetables for Fresh Consumption. Critical Reviews in Plant Sciences, 24 (3), 227-247. doi: http:// doi.org/10.1080/07352680591008628

27. Parisi, M., Giordano, L., Pentangelo, A., D’Onofrio, B., Villari, G. (2006). Effects of different levels of nitrogen fertilization on yield and fruit quality in processing tomato. Acta Horticulturae, 700, 129-132. doi: http://doi.org/10.17660/ actahortic.2006.700.19

28. Rosales, M. A., Cervilla, L. M., Sánchez-Rodríguez, E., RubioWilhelmi, M. del M., Blasco, B., Ríos, J. J. et. al. (2010). The effect of environmental conditions on nutritional quality of cherry tomato fruits: evaluation of two experimental Mediterranean greenhouses. Journal of the Science of Food and Agriculture, 91 (1), 152-162. doi: http://doi.org/10.1002/jsfa.4166 
29. Bénard, C., Gautier, H., Bourgaud, F., Grasselly, D., Navez, B., Caris-Veyrat, C. et. al. (2009). Effects of Low Nitrogen Supply on Tomato (Solanum lycopersicum) Fruit Yield and Quality with Special Emphasis on Sugars, Acids, Ascorbate, Carotenoids, and Phenolic Compounds. Journal of Agricultural and Food Chemistry, 57 (10), 4112-4123. doi: http://doi.org/10.1021/ jf8036374

30. Beckles, D. M. (2012). Factors affecting the postharvest soluble solids and sugar content of tomato (Solanum lycopersicum L.) fruit. Postharvest Biology and Technology, 63 (1), 129-140. doi: http://doi.org/10.1016/j.postharvbio.2011.05.016

31. Fernández-Ruiz, V., Sánchez-Mata, M. C., Cámara, M., Torija, M. E., Chaya, C., Galiana-Balaguer, L. et. al. (2004). Internal Quality Characterization of Fresh Tomato Fruits. HortScience, 39 (2), 339-345. doi: http://doi.org/10.21273/hortsci.39.2.339

Olesia Priss, Doctor of Technical Sciences, Professor, Department of Technology of Processing and Storage of Agricultural Products, Dmytro Motornyi Tavria State Agrotechnological University, Melitopol,
Ukraine, e-mail: olesyapriss@gmail.com, ORCID: https://orcid.org/ 0000-0002-6395-4202

Valentina Zhukova, PhD, Associate Professor, Department of Technology of Processing and Storage of Agricultural Products, Dmytro Motornyi Tavria State Agrotechnological University, Melitopol, Ukraine, e-mail: zhuzhuvf@gmail.com, ORCID: https://orcid.org/ 0000-0002-1963-659X

Serhii Holiachuk, PhD, Associate Professor, Department of Technologies and Equipment of Processing Industries, Lutsk National Technical University, Lutsk, Ukraine, e-mail: s.golyachuk@gmail.com, ORCID: https://orcid.org/0000-0002-4835-8154

Tetiana Karman, PhD, Associate Professor, Department of Techno$\log y$ of Processing and Storage of Agricultural Products, Dmytro Motornyi Tavria State Agrotechnological University, Melitopol, Ukraine, e-mail: tetiana.karman@tsatu.edu.ua, ORCID: https:// orcid.org/0000-0002-9313-554X 